\title{
The Right to Counsel at Lineups: Wade and Gilbert in the Lower Courts
}

\begin{abstract}
It is an understatement, of course, to say that the rights of a criminal defendant in pre-trial proceedings have expanded greatly in just the last few years. But in no area of the law was the development quicker, more startling, and perhaps more unexpected than the recent decisions regarding the right to counsel during the pre-trial out-of-court identification procedures and confrontations between suspects and witnesses. ${ }^{1}$
\end{abstract}

On June 12, 1967, the Supreme Court of the United States announced the right to counsel at lineups in two now well-known cases, United States $v$. Wade ${ }^{2}$ and Gilbert $v$. California. ${ }^{3}$ Stovall v. Denno, ${ }^{4}$ handed down the same day, made the constitutional requirement of the presence of counsel applicable only to confrontations for identification which occurred after the date of the decisions. The cases have engendered numerous academic discussions, at times passionate judicial reaction, ${ }^{5}$ Congressional legislation, ${ }^{6}$ and uncounted cases in the state

\footnotetext{
1 Rivers v. United States, 400 F.2d 935, 939 (5th Cir. 1968) (footnotes omitted).

2388 U.S. 218 (1967).

3388 U.S. 263 (1967).

4388 U.S. 293 (1967).
}

5 See State v. McKissick, 271 N.C. 500, 157 S.E.2d 112 (1967). After indicating its disagreement with the Wade decision, the court said, "Our almost two-centuries-old Constitution has not fundamentally changed ... but the construction of it has with the past few years. When any court or justice makes an interpretation not in conformity with those of John Marshall, Edward Douglas White, Oliver Wendell Holmes, William Howard Taft or Charles Evans Hughes, it is subject to scrutiny." Id. at 507, 157 S.E.2d at 118.

6 In June, 1968, Congress passed the Omnibus Crime Control and Safe Streets Act of 1968, 82 Stat. 197. Title II, § 701(b) of that legislation, 18 U.S.C. § 3502 (Supp. IV, 1969), reads as follows: "The testimony of a witness that he saw the accused commit or participate in the commission of the crime for which the accused is'being tried shall be admissible in evidence in a criminal prosecution in any trial court ordained and established under article III of the Constitution of the United States." Although the words of the statute themselves do not express the intent to overrule Wade and Gilbert, the implication is clear, and the dubious need only look to the Senate committee report for reassurance. The Senate committee described eyewitness testimony as "an essential prosecutorial tool" and labeled Wade "a harmful blow at the nationwide effort to control crime." The fact that an eyewitness prior to trial had identified the accused without a lawyer present "cannot in reason, law or commonsense justify such a disastrous rule of evidence, Nothing in the Constitution warrants it." See S. REP. No. 1097, 90th Cong., 2d Sess., in 1968 U.S. CODE CoNg. \& AD. NEws 2112.

The attempt of Congress to overrule the decision of the Supreme Court, along with 
and federal courts. The broad sweep of the Supreme Court's language in the Wade and Gilbert cases left this extension of the right to counsel clouded with ambiguities. The Supreme Court has not rendered any decisions in the field to eliminate the problems of interpretation. However the lower courts, who must determine the impact of the Supreme Court decisions on the rights of the criminal defendant, cannot escape the burden of applying the right announced in Wade and Gilbert on a daily basis.

An examination of the decisions of the lower courts of the state and federal systems demonstrates that, although the courts have not generally limited the impact of Wade and Gilbert to precise duplicates of the factual situation found in those two cases, there has been an unwillingness to extend the right to counsel at lineups to the "investigatory" stage of the criminal process. Equally, the courts have found that the right to counsel does not apply to an on-the-scene identification of a suspect, nor to an "investigatory" identification procured without the formalities of a lineup, nor to an identification occurring in a judicial proceeding, such as arraignment or preliminary hearing. Almost unanimously, the courts have refused to extend the right to counsel to identification from photographs, even the identifications that are conducted after the suspect is in custody. In addition, the courts have given a very wide latitude to the doctrine of the independent origin which saves an identification for evidentiary purposes despite the violation of the defendant's right to counsel at the lineup itself. This comment will analyze these restrictive interpretations of

the decisions relating to confessions, pose intriguing political and constitutional issues. For analyses, directed primarily at the Miranda sections of the statute, see, Note, Survey of Title II: Omnibus Crime Control and Safe Streets Act of 1968, 18 AM. U.L. REV. 157 (1968); Note, Title II of the Omnibus Crime Control Act: A Study in Constitutional Conflict, 57 GEo. L.J. 438 (1968); Comment, Title II of the Omnibus Crime Bill: A Study of the Interaction of Law and Politics, 48 NEB. L. REv. 193 (1968). It is the opinion of all three commentators that the changes directed at the Wade decision have no constitutional basis and will be declared unconstitutional if the challenge is ever made. Three federal courts have so far adverted to the existence of 18 U.S.C. $\$ 3502$, but no decision has been handed down dealing with the validity or the meaning of the section. See United States v. Davis, 399 F.2d 948, 952 (2d Cir.), cert. denied, 393 U.S. 986 (1968); Russell v. United States, 408 F.2d 1280, 1286 (D.C. Cir. 1969); United States v. Clark, 289 F. Supp. 610, 629-30 (E.D. Pa. 1968). The contention has been advanced that the statute successfully overrules Wade in the federal courts leaving it in effect only in the state courts, surely an anomalous situation. See Poole v. State, 216 So. $2 d$ 425, 426 (Miss. 1968); W. Ringel, Identification and Police Line-Ups, AdDENDA (1968). It may be a considerable time before anyone gets an authoritative interpretation of the statute. The Justice Department under the Johnson Administration sent directives to all the United States Attorneys prohibiting use of the Miranda and Wade provisions of Title II. It is unclear, of course, whether the directive will continue under the Nixon Administration. Note, Title II of the Omnibus Crime Control Act: A Study in Constitutional Conflict, 57 Gro. L.J. 438, 460 (1968). 
the Wade and Gilbert decisions and suggest additional developments of judicial and legislative regulations of identification procedures which are necessary to insure the protection of the rights of the criminal defendant which Wade and Gilbert were designed to provide.

\section{Wade, Gilbert, AND Stovall: ThE FAcTs}

Before considering in depth the interpretations which have been placed upon the "trilogy," a preliminary statement of the facts of the cases is in order. ${ }^{7}$ In Wade, the defendant was placed in a lineup several weeks after his indictment and arrest for robbery of a federally insured bank, without notice to and in the absence of his appointed counsel. At trial, the government relied on the in-court identification of the witnesses, and the facts of the lineup identification were brought out by the defense, including the fact that the defendant had been seen in the hall, in the custody of a federal agent, before the lineup was conducted. Alleging that the lineup violated his fifth amendment privilege against self-incrimination and his sixth amendment right to counsel, Wade moved for an acquittal or for the striking of the courtroom identifications. The motion was denied and he was convicted. The Fifth Circuit reversed, holding that the defendant's right to counsel had been violated. ${ }^{8}$ The Supreme Court, while denying that the lineup violated the defendant's fifth amendment protection against self-incrimination, held that the sixth amendment did guarantee Wade's right to counsel at the pretrial lineup. The identification lineup was a critical stage of the prosecution because of the risk that, intentionally or not, the police procedures could suggest to the witness that the defendant was the culprit. Adding to the critical nature of the lineup was the fact that the defendant himself had no way of observing the circumstances and reconstructing the suggestive aspects of the situation for use of his counsel in discrediting the identification testimony of the witness at trial. Counsel is required by the sixth amendment wherever his absence "might derogate from the accused's right to a fair trial,"9 and counsel at the pretrial lineup can eliminate some of the suggestive procedures and also can assure a meaningful

7 For a more detailed analysis of the decisions themselves, there are a considerable number of discussions in the law review literature. See, e.g., Comment, The Right to Counsel During Pretrial Identification Proceedings-An Examination, 47 NEB. L. REv. 740 (1968); Comment, Right to Counsel at Police Identification Proceedings: A Problem in Effective Implementation of an Expanding Constitution, 29 U. PITT. L. REv. 65 (1967); Comment, Lawyers and Lineups, 77 YALE L.J. 390 (1967); Note, United States v. Wade: A Case of Mistaken Identity, 1 J. MARSh. J.P.P. 285 (1968); 14 Loyola L. REv. 222 (1967-68); 51 MARQ. L. REv. 191 (1968).

8 Wade v. United States, 358 F.2d 557 (5th Cir. 1966).

9388 U.S. at 226. 
reconstruction of the facts of the lineup for the purpose of crossexamination of the identifying witness in the courtroom. ${ }^{10}$

Despite the violation of the right to counsel, the Supreme Court refused to hold that the courtroom identification of the witnesses who had viewed the defendant in the "tainted" lineup should be excluded on a per se basis. The case was remanded to the district court for a hearing where the court would determine if the in-court identification " 'has been come at by exploitation of that illegality or instead by means sufficiently distinguishable to be purged of the primary taint.' "11 The government would thus have the opportunity to prove that the identification was based upon observations of the suspect other than at the lineup, and if it successfully carried the burden of clear and convincing evidence, ${ }^{12}$ the in-court identification of the witness would be admissible despite the absence of counsel at the lineup. If the government did not carry this evidentiary burden, the defendant was entitled to a new trial at which the in-court identification of the witness was to be excluded. Despite the dire predictions of the Wade dissenters that in-court identifications would never be admissible if the prosecution was required to establish the existence of an independent source by clear and convincing evidence, ${ }^{13}$ it is apparent that expansive court interpretations of the test could create a trapdoor through which a defendant's Wade-Gilbert rights would regularly disappear. ${ }^{14}$

10 Id. at 236. The problem of the exact role which counsel is to play at identification confrontations is beyond the scope of this comment. For discussion of the issue, see, e.g., Comment, The Right to Counsel During Pretrial Identification Proceedings-An Examination, 47 NEB. L. REv. 740, 748-54 (1968); Comment, Right to Counsel at Police Identification Proceedings: A Problem in Effective Implementation of an Expanding Constitution, 29 U. PITT. L. REv. 65, 72-76 (1967); Comment, Lawyers and Lineups, 77 YALE L.J. $390,396-8$ (1967).

11988 U.S. at 241.

12 Id. at 240 .

$13 \mathrm{Id}$. at 251.

14 An analysis of the myriad lower court decisions finding the necessary "independent source" indicates that the courts are interpreting the test in a very broad fashion. See, e.g., Fitts v. United States, 406 F.2d 519 (5th Cir. 1969); State v. Boens, 8 Ariz. App. 110, 443 P.2d 925 (Ct. App. 1968); Shepard v. State, 213 So. 2d 11 (Fla. Ct. App. 1968); State v. Singleton, 253 La. 18, 215 So. 2d 838 (1968); Poole v. State, 216 So. 2d 425 (Miss. I968); State v. Cannito, 183 Neb. 575, 162 N.W.2d 260 (1968); State v. Woodard, 102 N.J. Super. 419, 246 A.2d 130 (Super. Ct. 1968); People v. Jacobsen, 57 Misc. 2d 1046, 294 N.Y.S.2d 46 (Nassau Co. Ct. 1968); People v. Jefferson, 55 Misc. 2d 96, 284 N.Y.S.2d 538 (Monroe Co. Ct. 1967); State v. Redmond, - Wash. -, 448 P.2d 938 (1968). But see United States v. Wilson, 283 F. Supp. 914 (D.D.C. 1968); State v. Stamey, 3 N.C. App. 200, 164 S.E.2d 547 (Ct. App. 1968). Considering these decisions, there may well at present be little distinction between the protection offered by the Wade-Gilbert right to counsel and the totality-of-circumstances criteria against which the courts measure a violation of due process in identification confrontations. The checklist of factors which should be considered in determining the presence of an independent source which was set out by the Wade court demonstrates the resemblance of the two approaches. The criteria included 
Two other limitations on the Wade decision should be mentioned. First, the Court stated that, of course, the.right to counsel at lineup could be negated by an "intelligent waiver."15 More intriguingly, the Court left open the possibility that "[1]egislative or other regulations .. . which eliminate the risks of abuse and unintentional suggestion at lineup proceedings and the impediments to meaningful confrontation at trial may also remove the basis for regarding the stage as 'critical.' "16

Factually, the Gilbert case was very similar. The petitioner had been identified in a post-indictment lineup in the absence of his counsel. However, at trial not only did the witnesses identify Gilbert in the courtroom, but they also testified that they had identified him at the lineup. The Court held that the same right to counsel applied to a state criminal defendant. However, one critical difference in the two cases was the per se exclusion of the testimony of the witnesses regarding the lineup itself. That testimony should have been excluded, and on remand, unless the state court found that the admission of the evidence was harmless error, the defendant was entitled' to a new trial. ${ }^{17}$

Stovall is generally cited for its ruling that the right to counsel at lineup would be applied only to identification confrontations which

"the prior opportunity to observe the alleged criminal act, the existence of any discrepancy between any pre-lineup description and the defendant's actual description, any identification prior to lineup of another person, the identification by picture of the defendant prior to the lineup, failure to identify the defendant on a prior occasion, and the lapse of time between the alleged act and the lineup identification. It is also relevant to consider those facts which, despite the absence of counsel, are disclosed concerning the conduct of the lineup." 388 U.S. at 241 (footnotes omitted). The application of the independent source test has been liberal in these first two years following the Wade and Gilbert decisions, but it is at least arguable that the independent source test will and should be narrowed as law-enforcement officers become more familiar with the demands of the right to counsel at lineups. When that happens the scope of the right to counsel will be more important than it presently appears to be, and on this premise, the discussion in this paper will continue.

15388 U.S. at 237. The "waiver" issue under Wade may some day be as complex as it has become under Miranda. See Comment, Waiver of Rights in Police Interrogations: Miranda in the Lower Courts, 36 U. CHr. L. REv. 413 (1969).

16388 U.S. at 239 (footnotes omitted).

17 Gilbert v. California, 388 U.S. at 274. The implications of the use of the harmless error standard is another problem area of the two decisions. The Supreme Court recently refused to rule on the harmless error point in remanding a case in which it found a due process violation under Stovall in the conduct of the pretrial confrontation. The lower court must rule upon it. Foster v. California, 394 U.S. 440 (1969). See also Solomon v. United States, 408 F.2d 1306 (D.C. Cir. 1969); Ruona v. United States, 403 F.2d 215 (9th Cir. 1968); People v. Geralds, 29 App. Div. 2d 984, 290 N.Y.S.2d 10 (Sup. Ct. 1968). For a general discussion of the problems of the harmless error doctrine, see Mause, Harmless Constitutional Error: The Implications of Chapman v. California, 53 MinN. L. Rev. 519 (1969). 
occurred after the date of the three decisions, June 12, 1967.18 However, the Court also announced that an identification confrontation may be challenged on the grounds that it "resulted in such unfairness that it infringed [the defendant's] right to due process of law."10 Upon an evaluation of the "totality of circumstances" surrounding the use of the confrontation, the Court concluded that a hospital room identification of the defendant by the critically wounded victim was not "so unnecessarily suggestive and conducive to irreparable mistaken identification" as to deny due process. ${ }^{20}$ The due process challenge to the legality of the identification was thus assured to those defendants who were not able to utilize the Wade and Gilbert rulings because of the non-retroactive status which the Supreme Court had assigned to them.

\section{Limitations on the Scope of Wade-Gilbert}

In the past two years, the courts have confronted numerous situations where they have been required to decide whether a particular factual situation does or does not fall within the Wade-Gilbert requirement of counsel at identification procedures. Due to the silence of the Supreme Court, this pattern of judicial interpretations of the scope of the Wade-Gilbert right to counsel is presently crucial. Three areas where the courts have given answers concerning the scope of the right to counsel at lineups are presented and discussed below. The first is the extremely broad area of the pre-indictment lineup; the second is the narrower ambit of the lineup conducted during the investigatory stage of the case; and the third is the restricted situation, within that of investigation, where an on-the-scene identification is in issue. In answering the questions which have been presented to them, the courts have fashioned boundaries for the applicability of the WadeGilbert right to counsel; these boundaries are identified and evaluated in an effort to determine whether they are desirable and appropriate limitations on the right to counsel at identification procedures.

\section{A. Pre-Indictment Identification}

Both of the cases in which the Supreme Court announced the right to counsel at lineups involved post-indictment lineups and situations where counsel had already been appointed for the defendant. The Court found that here at least the risks of suggestability in the lineup procedure and the inability of the defendant to reconstruct the events for the purpose of cross-examination at trial rendered the lineup

18388 U.S. at 296.

$19 \mathrm{Id}$. at 299.

$20 \mathrm{Id}$. at 302. 
identification a critical stage of the prosecution demanding the presence of counsel. However, the Court at no point indicated that the post-indictment lineup in the absence of appointed counsel was the only identification procedure where the conclusionary label of "critical stage" would result in the need for counsel. Indeed, the Court indicated that it was required to "scrutinize any pretrial confrontation"21 to determine if it was a critical stage. The exclusionary rule of Wade and Gilbert was designed "to deter law enforcement authorities from exhibiting an accused to witnesses before trial for identification purposes without notice to and in the absence of counsel."22 The sweep of the language is awesome and open-ended and is limited only by the Court's implied concession that although no "countervailing policy considerations" 23 had been advanced against the requirement of counsel in the Wade and Gilbert cases, perhaps some might be advanced in future situations.

In general, the courts have not confined the impact of the Wade and Gilbert rulings to their narrowest possible sphere of influence, despite the fact that the prosecution in general urges them to do so. Two federal district courts have so far ruled that Wade and Gilbert are not limited to post-indictment situations; ${ }^{24}$ both of those decisions resorted to the label of the critical stage without going into the reasons for the "criticalness." 25 One of those courts seemed to consider that the live confrontation between the defendant and witnesses was the characteristic which linked the case at bar to Wade, ${ }^{26}$ in addition to the fact that the focus of the police work had narrowed down to the particular defendant involved at the time of the lineup. ${ }^{27}$ Other courts have decided that the factors of unreliability ${ }^{28}$ and the impossibility of meaningful cross-examination at trial ${ }^{29}$ cannot reasonably be limited to postindictment situations, and thus neither can the Wade requirements.

21 United States v. Wade, 388 U.S. at 227. Justice White, dissenting, noted that the rule would apply to any identification procedure "whether before or after indictment or information." Id. at 251.

22 Stovall v. Denno, 388 U.S. at 297.

23 United States v. Wade, 388 U.S. at 237.

24 United States v. Clark, 289 F. Supp. 610, 626.7 (E.D. Pa. 1968); United States v. Wilson, 283 F. Supp. 914, 915 (D.D.C. 1968) (both stationhouse identifications).

25 United States v. Clark, 289 F. Supp. 610, 627 (E.D. Pa. 1968); United States v. Wilson, 283 F. Supp. 914, 915 (D.D.C. 1968).

26 United States v. Clark, 289 F. Supp. 610, 625 (E.D. Pa. 1968).

27 Id. at 627 .

28 See, e.g., People v. Pedercine, 256 Cal. App. 2d 328, 336, 63 Cal. Rptr. 873, 878 (Ct. App. 1967) (dictum).

29 See, e.g., People v. Fowler, 270 Cal. App. 2d -, 76 Cal. Rptr. 1 (Ct. App. 1969); Palmer v. State, 5 Md. App. 691, 249 A.2d 482 (Ct. Spec. App. 1969). 
In People v. Palmer, ${ }^{30}$ the Illinois Supreme Court expressed a decided disagreement with this trend of decisions; it held that in Illinois the Wade-Gilbert right to counsel would only apply to lineups conducted after the indictment. The court apparently relied mainly upon the opening sentence in the Wade opinion, which stated that the lineup was held after indictment and after the appointment of counsel, ${ }^{31}$ and upon a narrow characterization of the cases in a later decision by the Supreme Court. ${ }^{32}$ The Illinois court did not analyze the situation in the case before it in terms of the risks of suggestability nor in terms of the need to reconstruct the identification at trial, the flexible approach which the rest of the Supreme Court decision seems to require.

The "extent of this right [to counsel at pretrial confrontations] in particular circumstances has yet to be authoritatively determined,"33 and the reluctance of a court to extend rights with which it, as well as the Supreme Court, is unfamiliar, is understandable. ${ }^{34}$ Admittedly, limiting the scope of the right to counsel by the application of the simple pre-/post-indictment dichotomy would lend itself to easy administration by the courts. Unfortunately, it would also leave the police in the position to manipulate the applicability of the right to counsel by holding all identification procedures before the indictment, thus defeating the aim of the Wade and Gilbert rulings. The test is too mechanical to be worthy of a judicial system where attention has

30 People v. Palmer, 41 Ill. 2d 571, 244 N.E.2d 173 (1969).

31 "The question here is whether courtroom identifications of an accused at trial are to be excluded from evidence because the accused was exhibited to the witnesses before trial at a post-indictment lineup conducted for identification purposes without notice to and in the absence of the accused's appointed counsel." 388 U.S. at 219-20.

32 Simmons v. United States, 390 U.S. 377, 382-3 (1968). For the view that cases are limited to post-indictment lineups, see Comment, The Right to Counsel During Pretrial Identification Proceedings-An Examination, 47 NEB. L. REv. 740, 747 (1968); 9 WM. \& MARY L. REv. 528, 533 (1967). For the opposite view, see 51 MarQ. L. REV. 191, 194 (1968).

33 United States v. O'Connor, 282 F. Supp. 963, 964 (D.D.C. 1968).

34 See Caples v. United States, 391 F.2d 1018, 1021-2 (5th Cir. 1968) (court in dicta distinguished a pre-Wade case at least partly on the basis that it was a pre-indictment lineup.) Several courts have also refused to rule on the applicability of Wade to preindictment situations in cases where such a ruling would have been dicta. See, e.g., People v. Crosslin, 251 Cal. App. 2d 968, 981, 60 Cal. Rptr. 309, 318 (Ct. App. 1967); State v. Mentor, 433 S.W.2d 816 (Mo. 1968); State v. Matlack, 49 N.J. 491, 499 n.I, 231 A.2d 369, 373 n.1 (1967); State v. Sinclair, 49 N.J. 525, 545 n.1, 231 A.2d 565, 575 n.l (1967); State v. Williams, 97 N.J. Super. 573, 603, 235 A.2d 684, 700 (Bergen Co. Ct. 1967). In light of the necessity which faces police of dealing with the Wade-Gilbert ruling, the decision of an Oklahoma court giving guidance as to the conduct of lineups, albeit in dicta, seems the more desirable approach and also more in conformance with the Supreme Court's call for guidelines. Thompson v. State, 438 P.2d 287, 289 (Okla. Crim. App. 1968). 
been increasingly devoted to the realities of the criminal process rather than to its labels. The concerns of the Supreme Court with suggestability and the need for reconstruction of the identification procedures at trial cannot with any rationality be limited to the post-indictment situation, although there may be other limits on the right to counsel even where these concerns are present. It is likely that the great majority of the courts will not impose any such artificial barrier.

\section{B. The "Investigatory Stage" Identification}

When the courts have ruled upon the right to counsel at lineups conducted in the so-called "investigatory stage" of a case, they have been less generous in interpreting the Wade-Gilbert rule. The investigatory stage apparently encompasses the entire time period up until a charge is made against the suspect for the particular offense under consideration. While there would seem to be considerable overlap between the pre-indictment stage and the investigatory stage, the courts have nevertheless been more restrictive in their application of the Wade-Gilbert rule to the latter, perhaps because of the lack of a mechanical pre-/post-indictment type formula to guide their decisions. With respect to the investigatory stage, the sweeping language of the Supreme Court in the Wade-Gilbert decisions once again leaves the right-to-counsel question open; nowhere did the Court indicate that the investigatory stage of the case was immune from the requirement of counsel. ${ }^{35} \mathrm{It}$ is also in the situations which have been labeled investigatory that confrontations for identification which do not take the form of the lineup are likely to occur, but once again the Supreme Court's decisions do not base the strictures of the right to counsel on the form which the identification confrontation assumes. ${ }^{36}$

The confrontations which occur in the investigatory stage of the case vary significantly in detail. Frequently a defendant who has already been arrested in connection with another offense will be placed in the challenged lineup for the purpose of possible identification by the victims or witnesses of a second unsolved crime. ${ }^{37}$ In other cases, there has been no arrest at all, and the confrontations have been informal-that is not in the form of a lineup at the stationhouse. ${ }^{38}$ All

\footnotetext{
35 See text at notes $21 \& 22$ supra.

36 Id.

37 See, e.g., State v. Mentor, 433 S.W.2d 816, 818 (Mo. 1968); Lujan v. State, 428 S.W.2d 336 (Tex. Crim. App. 1968) (comparable, not exact facts). It appears that holding lineups for this sort of "open crime" is a prevalent police practice. Occasionally, the suspects are only placed in lineups when the unsolved crimes in question occurred in the same geographic area as the one for which they are already under arrest, or where the open crimes involve a similar modus operandi.

38 See, e.g., State v. Bratten, - Del. Ch. -, 245 A.2d 556 (Super. Ct. 1968) (victim of
} 
of these informal confrontations have been "arranged" by the police with a specific crime in mind, and the crime is the same one for which the defendant is later tried, and in which he raises the issue of the out-of-court identification. In some cases, the crime itself is unknown to the police at the time of the confrontation which yields the challenged identification. ${ }^{39}$

Considering the factual variations which occur in investigatory identifications, some division among the courts might have been expected as far as the application of the Wade and Gilbert right to counsel is concerned. The unanimity with which the courts have exempted these identification confrontations from the requirement of counsel is thus particularly striking. Even more intriguing is the failure of all the courts save one to go through even the motions of analyzing the case before them in terms of the risks of suggestability and the need for reconstruction of the confrontation at trial. The one court which did look for the presence of a critical stage failed to find it, and relied, not on the absence of the two criteria which the Supreme Court used, but on what it felt was the slim chance for misidentification due to the short lapse of time between the crime and the identification..$^{40}$

To the extent that the courts have expressed the motivation behind their unequivocal denial of the extension of the Wade-Gilbert right to counsel, it has been in terms of the desire not to hamper the police in their law enforcement activity. A conviction that a "common sense approach to the problems which confront policemen must be taken into consideration in the application of the law to the facts" 41 pervades these decisions. It is not difficult to understand the concern of the judiciary that the police not be overly burdened with requirements to provide counsel before they take any action toward the solution of an offense. However, in their zeal to guarantee efficient law enforcement, the courts have too often ignored an analysis of investigatory stage con-

robbery called to the scene of a minor automobile accident by police and there identified defendant); State v. Chuning, 201 Kan. 784, 443 P.2d 248 (1968) (witness taken to a nearby courthouse and identified defendant as one of a group "milling around in the hall'); Trask v. State, - Me. -, 247 A.2d 114 (1968) (defendant in custody on another charge taken to a hospital for identification by the victim).

39 See, e.g., United States v. Davis, 399 F.2d 947 (2d Cir.), cert. denied, 393 U.S. 986 (1968) (defendant taken into custody for walking on a thruway, identified by the toll collector as the driver of a car, known to have been abandoned on the thruway, but later found to be stolen); State v. Satterfield, 103 N.J. Super. 291, 247 A.2d 144 (Super. Ct. 1968) (defendant identified as one who had been acting suspiciously in a police investigation of suspicious activity; suspicious activity later found to involve possession of narcotics).

40 State v. Bratten, - Del. Ch. -, 245 A.2d 556, 559 (Super. Ct. 1968).

41 Id. Accord, State v. Satterfield, 103 N.J. Super. 291, 247 A.2d 144 (Super. Ct. 1968) (no extension of Wade to "routine police investigative activity"). 
frontations which might well indicate that some do fall within the scope of the Wade-Gilbert right to counsel.

A fundamental concern of the Supreme Court in the Wade and Gilbert decisions was first of all to minimize the risk of intentional and unintentional suggestiveness of the lineup identification. Substantial dangers of suggestiveness would seem to be present in the confrontations which occur at the investigatory stage. If the identification is made from a lineup, ${ }^{42}$ many of the same problems that characterize the lineup in later stages of the prosecution exist, except that the police may not be quite as convinced that the defendant is the criminal and may not therefore be as tempted to indicate their predilections to the witness. Multiple witnesses may still reinforce each others' identification if they are allowed to communicate, and the defendant is just as likely to be seen in a damning situation before the investigatory lineup as when the identification occurs later.

The informal confrontation at the investigatory stage, when the crime is known to the police, but the defendant has not yet been arrested, ${ }^{43}$ poses even more serious problems of suggestiveness due to the fact that the informal confrontation is likely to be one where the victim or witness is asked to identify only the single individual placed before him. The identifier can have little doubt that the police have some fairly substantial reason to suspect this individual or they would not have bothered to arrange the meeting. The non-lineup confrontation at the investigatory stage, when the crime itself is unknown to the police, ${ }^{44}$ analytically poses the same dangers of suggestiveness, but at least the risk of intentional suggestion should be discounted by the fact that the law-enforcement authorities have a less intense interest in connecting the individual involved with any particular crime since they are not aware of the crime with which the defendant is later charged.

The second concern of the Supreme Court was that absence of counsel would effectively deny the defendant the opportunity to reconstruct the identification circumstances and thus virtually eliminate his ability to challenge the reliability of the identification at trial. The problems of reconstruction from the investigatory stage lineup parallel the problems of reconstruction when the lineup is conducted later in the case. The informal confrontation where the victim or witness is faced with a single individual arguably offers less difficulty, since there is not even the pretense of a non-suggestive presentation. Still the de-

42 see text at note 37 supra.

43 See text at note 38 supra.

44 See text at note 39 supra. 
fense counsel may have difficulty in discovering what, if anything, was said to the identifiers, as well as other pertinent details.

Since both of the dangers with which the Supreme Court was concerned are present to some degree in every confrontation which occurs at the investigatory stage, the courts should look to analogies in other cases where the rights of the criminal defendant have been considered for principles upon which they could base the presence of the Wade and Gilbert right to counsel. Two possible solutions are suggested by the confession cases dealing with the right to counsel during police interrogation. ${ }^{45}$

The "custody" criterion as developed in Miranda $v$. Arizona $a^{46}$ and Orozco $v$. Texas ${ }^{47}$ would require that, once a person was in custody at the station or "otherwise deprived of his freedom in any significant way," the police not hold a lineup or a non-lineup confrontation without informing the defendant of his right to have counsel present. This requirement would exist even if the defendant had not been charged with the particular crime for which the identification confrontation was to be held. The application of the "custody" criterion as a limiting principle for the application of Wade seems to be recommended by the American Law Institute as the draft of the code of pre-arraignment procedure concentrates on the "arrested" person, ${ }^{48}$ with no concern for the relation between the reason for the arrest and the reason for the holding of the lineup.

If "custody" were the criterion which triggered the Wade right to counsel, the defendant in custody could then waive his right to counsel, or the police would be required to await the presence of or at least reasonable time for the appearance of counsel. The Supreme Court has suggested that substitute counsel could be provided where necessary to avoid prejudicial delay. ${ }^{40}$ When the suspect is already in custody for another crime, the problem of delay seems the least troublesome. To request that his attorney for the other offense be present at the "open crime" lineup, or indeed to expedite the appointment of an attorney for the other charge in order to assure the presence of

\footnotetext{
45 In Escobedo v. Illinois, 378 U.S. 478 (1964), the Supreme Court held that where a police "investigation is no longer a general inquiry into an unsolved crime but has begun to focus on a particular suspect" in police custody the protection of the right to counsel applies to interrogations. Id. at 490. In Miranda v. Arizona, 384 U.S. 436 (1966), the general condition of custody was held to trigger the right to counsel during interrogation.

46384 U.S. 436 (1966).

47394 U.S. 324 (1969).

48 Ali Model Code of Pre-Arraignment Procedure \$§ A5.09, B108 (Tent. Draft No. 1 , 1968).

49 United States v. Wade, 388 U.S. 218, 237 (1967).
} 
counsel at a possibly crucial confrontation is not the sort of difficulty which should dissuade the courts from requiring the presence of counsel. If the suspect is in custody but has not been charged with any crime, delay of identification might be greater unless substitute counsel were utilized, but again the difficulty is not insurmountable. However, the custody criterion as it was developed and applied in the confession cases was aimed at the protection of the suspect from coercion. The problem in the lineup situation is hardly coercion. This suggests that the criterion may not be applicable with equal appropriateness to both problems.

The application of the "focus" criterion of Escobedo v. Illinois $s^{50}$ would not extend the Wade protection to all "open crime" lineups, the result which the custody test would accomplish. This approach would, however, reach many informal confrontations arranged by the police which often do not assume the form of a lineup and often occur outside the stationhouse. ${ }^{51}$ Since these identifications can be made when the individual is under no restraint or under a degree of restraint which might not qualify as "custody," such as when he is waiting for the police officer to fill out an accident report, they might well escape the protection of the Wade decision if the "custody" criterion were to be utilized. The "focus" criterion takes into consideration the state of the policeman's mind, rather than the physical constraint under which the individual suspect has been placed. Since "focus" is an indicator of a state of mind, it seems likely that it may be an equally good indicator of the possibility of deliberate police abuse of the identification procedure, which also arises out of a state of mind, i.e., the belief in the guilt of a particular individual.

It is worthwhile to catalogue briefly the possible identification situations and note which would fall under the Wade protection if the focus criterion were applied by the courts. The stationhouse identification, whether in the form of a lineup or a single-man "show-up,"s2 where the police had the individual in custody for the particular crime for which the lineup was held or for a crime which they had reason to believe was linked with the particular crime for which the lineup was

50378 U.S. 478 (1964).

51 The ALI Draft does not consider the problems raised by the informal confrontation. See Ali Model Code of Pre-Arraignment Procedure, supra note 48, at 32.

52 See, Note, Due Process Considerations in Police Showup Practices, 44 N.Y.U.L. Rev. 377 (1969), for an interesting discussion of the problems of due process which are raised by the single-man confrontation with the victim or witness for identification purposes. The author suggests that "the product of a nonessential showup, even if conducted in counsel's presence, should not be admissible in evidence," although the state should have the chance to prove that the witness could identify the defendant independently of the showup. Id. at 390-93. 
held, indicates sufficient focus on one individual and sufficient danger of suggestion by the police to require counsel to be present. The informal confrontation arranged outside the stationhouse, whether in the single-man form or where the identifier must pick from a larger group, still offers sufficient focus, as is indicated by the confrontation being arranged by the police to begin with. The necessary focus would not be present, however, if someone in custody for disorderly conduct were simply placed in the lineup to provide the appropriate number of bodies. Nor would it be present if the informal group confrontation yielded an identification which the police had not anticipated.

The distinctions noted above depend on the absence of focus, one primary factor which could trigger deliberate police suggestion to the witnesses. However, even in the cases which the focus criterion would not place under the Wade protection, there are arguably still dangers of unintentional suggestiveness and of the future defendant's inability to reconstruct the circumstances of the identification. Perhaps in this situation the solution involves a weighing of the possible prejudice to the defendant against the costs to the legal system of providing counsel. In the case of the "open crimes" lineup, if the individual placed in the lineup had already been charged with another serious offense, and certainly if he already has counsel appointed, it would not be a serious burden to the police either to have counsel present or obtain a waiver for the second, and successive, lineups. However, if the individual placed in the lineup was someone charged with a minor offense, such as the derelict in custody for disorderly conduct, the burden upon the law-enforcement machinery of supplying counsel in each lineup might be considerable when weighed against the rather remote risk of prejudice to the individual whom the police do not suspect of the offense with regard to which the lineup is held. The focus criterion, with this modification and others which the courts would develop, seems to be a natural, or at least appropriate guideline, in general, for the presence of counsel at identification procedures.

\section{On-the-scene Identification}

If the courts comply with the suggested criterion of focus for the application of the Wade and Gilbert right to counsel, the issue of the on-the-scene identification inevitably arises. That is, does the policeman, who hears a woman screaming a half-block behind him and who turns to grab a man running hurriedly in the opposite direction, have to take victim, witness, and possibly innocent jogger to the police station, notify and obtain counsel for the suspect before he asks the 
woman if this is her assailant? In the meantime, of course, it is quite possible that the offender has made good his escape, at least for the time being. Yet, there is certainly focus upon that particular suspect. Perhaps this was one of the situations which the dissenters had in mind when they objected to the Wade rule, at least partly on the ground that it would apply to a "face-to-face encounter between the witness and the suspect alone, regardless of when the identification occurs, in time or place." 53 In Rivers $v$. United States, ${ }^{54}$ the Fifth Circuit, holding that the right to counsel applied where the suspect was shown to the victim who was in an ambulance awaiting transportation to the hospital, stated that "most, perhaps all, confrontations occuring after arrest will fall within the rules announced in Wade and Gilbert." "55 That court also doubted whether even "an absolute necessity for speed would create an exception to Wade-Gilbert rules .. . in light of the Court's language in Wade that the right to counsel cannot be brushed aside because a lawyer may cause obstruction and delay."56

Yet, most lower courts have refused to extend the Wade-Gilbert right to counsel to the on-the-scene identification. In Wise $v$. United States, ${ }^{57}$ a case involving a pre-Wade confrontation, the District of Columbia Circuit declined to rule on the right to counsel at such onthe-scene confrontations, noting that the Wade decision did not expressly consider such situations. ${ }^{58}$ In rejecting the defendant's due process attack on a confrontation proximate to the scene and time of the offense, the court observed that on-the-scene identifications promote fairness by assuring reliability. The court also recognized the suggestability of the presentation of one suspect in police custody to the victim or witness; ${ }^{59}$ this suggestiveness weighs on the side of the balance for extending the Wade proscriptions to these situations. The factors on the other side of the scale were expressed tersely, in the first case involving a post-Wade on-the-scene confrontation, as a need for a commonsense appreciation of the problems that the police

53388 U.S. at 251.

54400 F.2d 935 (5th Cir. 1968).

$55 I d$. at 939.

56 Id. at 940 n.12. See also, Comment, Lawyers and Lineups, 77 YALE L.J. 390, 394 (1967).

57383 F.2d 206 (D.G. Cir. 1967), cert. denied, 390 U.S. 964 (1968).

58 Id. at 209 n.9.

$59 \mathrm{Id}$. at 209. For other on-the-scene confrontations upheld against due process attack, see Solomon v. United States, 408 F.2d 1306 (D.C. Cir. 1969); Stewart v. United States, No. 20,983 (D.C. Cir., Feb. 10, 1969); Young v. United States, 407 F.2d 720 (D.C. Cir. 1969); Bates v. United States, 405 F.2d 1104 (D.C. Cir. 1968).

60 Commonwealth v. Bumpus, - Mass. -, 238 N.E.2d 343, 347 (1968). 
face in law enforcement. ${ }^{60}$ The only other state court to decide the issue commented, "If such confrontations as this [fifteen minutes after offense at the scene of the crime] violate our Constitution because they are 'suggestive,' then much of the evidentiary material which forms the grist of the fact-finding machinery in our courts should as well be constitutionally banned for unreliability," and added that pretrial "coaching" of witnesses was more suggestive than the confrontation in the case at bar. ${ }^{61}$

The only court to articulate in any detail the problems and the solutions to the on-the-scene confrontation issue is the Circuit Court of the District of Columbia. The issue was a troublesome one within the Circuit. One district court held that an on-the-scene identification conducted within minutes of the offense was not admissible in evidence and that no subsequent in-court identification could escape the taint of the initial identification conducted without counsel..$^{62}$ The court appealed to the Circuit Court for guidelines since it felt that the broad language of Wade arguably compelled this result. In Russell v. United States, ${ }^{63}$ the Circuit Court decided that Wade does not apply to a prompt confrontation with an eyewitness at the scene of the crime. Limiting its holding to on-the-scene identifications which occur within minutes of the crime, ${ }^{64}$ the court found that the dangers of suggestability inherent in confrontations of the witness with a single suspect were outweighed by the problems of delay in the identification proceedings undertaken with counsel present, of possible overnight detention of innocent individuals, and of the possible interruption of the search for the real criminal. ${ }^{65}$ These problems combine to form a "compelling reason"66 for not requiring counsel to be present. The District of Columbia Circuit also remarked, in a different case, that such "on-the-spot" identifications should be confined "to situations in

61 State v. Boens, 8 Ariz. App. 110, 113, 443 P.2d 925, 928 (Ct. App. 1968). This court hazarded the guess that the Supreme Court was motivated by a concern that the rich have no advantage over the poor in criminal cases. Neither, the court suggests, would have had counsel at this middle of the night confrontation. Id.

62 United States v. Kinnard, 294 F. Supp. 286 (D.D.C. 1968).

63408 F.2d 1280 (D.C. Cir. 1969). Accord, Washington v. United States, No. 22,022 (D.C. Cir., Feb. 28, 1969).

64408 F.2d at 1284 n.20.

$65 I d$. at 1283-4. The heart of the court's reasoning follows: "Balancing all the doubts left by the mysteries of human perception and recognition, it appears that prompt confrontations in circumstances like those of this case will if anything promote fairness, by assuring reliability .... This probability, together with the desirability of expeditious release of innocent suspects, presents 'substantial countervailing policy considerations' which we are reluctant to assume the Supreme Court would reject. We therefore conclude, with some hesitation, that Wade does not require exclusion of McCann's [the witness] identification." Id. at 1284 (footnotes omitted).

66 United States v. Wilson, 283 F. Supp. 914,916 (D.D.C. 1968). 
which possible doubts as to identification needed to be resolved promptly; absent such need the conventional line-up viewing is the appropriate procedure." 67

The cautious approach of the District of Columbia Circuit to the exemption of the on-the-scene identification has much to recommend it. The limitations on the exemption mean that the majority of informal confrontations arranged by the police would not escape the Wade-Gilbert strictures, and also mean that the only identifications which would qualify as "on-the-scene" would be those occurring very near in time and place to the commission of the offense. The conclusion of the court that such immediate identifications promote the accuracy of the identification may be challenged, but it at least is a conclusion as to which reasonable men may differ, and the countervailing policy considerations may indeed form a reasonable basis for exempting such on-the-scene identifications from the general criterion of focus which might otherwise import the protection of counsel into the situation. The exemption should be strictly construed to eliminate possible abuse. In addition, there would seem to be no reason why the police should not conduct a lineup with the same suspect and victim or witness at a later time, with counsel present, to test the accuracy of the on-the-scene identification.

\section{The Mandatory Lineup}

The presence of counsel at lineups and even the alternative legislative regulation of the lineup procedures will accomplish nothing if the police can avoid holding lineups at all. A requirement based upon due process that the police conduct a lineup with counsel present in every case where the identification of the victim or the witness will be introduced at trial, with narrowly defined exceptions for the onthe-scene identification and the emergency situation, for instance, where the viction is dying, is one possible solution to the problem.

Initial corporeal identifications of the defendant at the preliminary hearing; ${ }^{68}$ the arraignment, ${ }^{69}$ and even at trial ${ }^{70}$ are not uncommon and would appear to be subject to the same objections as single-man showups. Due process is likely to be violated when the suspect is presented singly to the identifier by the police before formal court pro-

67 Bates v. United States, 405 F.2d 1104, 1106 (D.C. Gir. 1968).

68 See, e.g., United States v. Davis, 407 F.2d 846 (4th Cir. 1969); People v. Jacobsen, 57 Misc. 2d 1046, 294 N.Y.S.2d 46 (Nassau Co. Ct. 1968); Tyler v. State, 5 Md. App. 265, 246 A.2d 634 (Ct. Spec. App. 1968).

68 United States v. Lipowitz, 407 F.2d 597 (3d Cir. 1969).

70 Fitts v. United States, 406 F.2d 518 (5th Cir. 1969); Borchert v. United States, 405 F.2d 735 (9th Cir. 1968); State v. Hunsucker, 3 N.C. App. 281, 164 S.E.2d 507 (Ct. App. 1968). 
ceedings because of the suggestiveness of the one-to-one confrontation. The suggestiveness may well be increased when the victim or witness is asked to identify a single individual in the context of a judicial proceeding, where it is evident that the police are sufficiently sure of their choice to charge the suspect, and he has clearly become the accused.

In Tyler v. State, ${ }^{71}$ the Maryland Court of Special Appeals held that an identification made at a preliminary hearing did not change the nature of that proceeding to a critical stage requiring the presence of counsel. The court simply remitted the evidence of the suggestability of the identification to the jury along with the rest of the evidence in the case. This might be a feasible solution if eye-witness identifications were evaluated in the same way as other evidence by the jury. But if, as one commentator has suggested, the jury is generally "unduly receptive to identification evidence," 72 simply presenting the jury with the possibility of mistaken identifications is inadequate protection against possible prejudice to the defendant.

Identifications made at judicial proceedings equally pose problems for the defendant as far as reconstruction for the purpose of trial is concerned. The opinion of the Maryland Court of Special Appeals to the contrary notwithstanding, ${ }^{73}$ an identification which takes place in the setting of a judicial proceeding may well be unreviewable. ${ }^{74}$ Reliance on the testimony of the witnesses themselves may produce little or no information, and the defendant is certainly in a no less vulnerable position as far as observing what occurs in the courtroom than he is in the lineup confrontation where the Supreme Court imposed the right to counsel.

Admitting that risks of suggestiveness and difficulties of reconstruction may well exist when an identification occurs in the preliminary hearing or at the arraignment, could the problems be solved by imposing the requirement of counsel at all of the proceedings where an identification occurs without resorting to the requirement of a mandatory lineup? Arguably, counsel cannot be an effective witness to all that takes place in the courtroom during such a proceeding, and it is the role of a trained witness which the Supreme Court has assigned to him in the Wade-Gilbert lineup situation. More importantly, the serious danger of suggestiveness remains unresolved even in the presence of counsel if identification is permitted at a judicial proceeding.

715 Md. App. 265, 246 A.2d 634 (Ct. Spec. App. 1968).

72 P. WAil, Eye-Witness Identification in CRiminal Cases 19-23 (1965).

73 Tyler v. State, 5 Md. App. at 271-3, 246 A.2d at 688-9 (court noted that the proceeding was a public one under the direction of the judicial officer, that the defense would be able to cross-examine the state's witnesses fully and call its own witnesses, including the judicial officer who presided).

74 Dade v. United States, 407 F.2d 692, 695 (D.C. Cir. 1968) (concurring opinion). 
Unless Wade and the future decisions of the Supreme Court lead to the requirement of a mandatory lineup with counsel present, it is possible that the potential prejudice of the lineup will be replaced by the definite suggestiveness of identifications during judicial proceedings which even the presence of counsel cannot eliminate. ${ }^{75}$

It is rather difficult to evaluate judicial receptiveness to a mandatory lineup requirement at this point, but there has been concern over the failure of the police to hold lineups when there was no satisfactory reason for not doing so. ${ }^{76^{\circ}}$ Chief Judge Bazelon of the District of Columbia Circuit has observed that " $[t]$ he police practice of allowing witnesses and victims of crimes to identify suspects in the unstructured, largely unreviewable surroundings of the Court of General Sessions could certainly not be tolerated after Wade v. United States."77 In Wright $v$. United States, ${ }^{78}$ when the District of Columbia Circuit remanded for more facts a case in which the defendant claimed a due process violation because he was shown singly to the witness, Judge Bazelon, dissenting, said, "[W]e must insist on the fairest feasible identification procedures and not rely on the courts' ability to gauge the psychological effects of more suggestive procedures." $79 \mathrm{He}$ would have required the government to show on remand that the failure to hold a lineup was justified; if not, he would have held it a violation of due process. ${ }^{80}$ Two other courts have found what appear to be per se violations of due process in the mere failure to hold lineups. ${ }^{81}$

Judicial opinion is not unanimous, however. In United States $v$. Davis, ${ }^{82}$ the Fourth Gircuit upheld an identification made at a preliminary hearing with counsel present and stated that "[d]ue process does not require that every pretrial identification of a witness must be con-

75 See Panel Discussion: The Role of the Defense Lawyer at a Line-up in the Light of the Wade, Gilbert, and Stovall Decisions, 4 Grrm. L. BuLl. 273, 290-1 (1968) (recommending the mandatory lineup). See also Note, Due Process Considerations in Police Showup Practices, 44 N.Y.U.L. REv. 377 (1969) for one possible method of handling single-man identifications.

76 See Bates v. United States, 405 F.2d 1104, 1106 (D.C. Cir. 1968); United States v. Trivette, 284 F. Supp. 720, 723 (D.D.C. 1968); Commonwealth v. Choice, 211 Pa. Super. 176, 178, 235 A.2d 173, 175 (Super. Ct. 1967) (dissenting opinion). See also Moore v. State, 424 S.W.2d 443, 444 (Tex. Crim. App. 1968) (defendant rather ineptly claiming right not to be identified except when seated or standing with similar persons).

77 Dade v. United States, 407 F.2d 692, 695 (D.C. Cir. 1968) (concurring opinion) (preWade confrontation upheld against due process challenge).

78404 F.2d 1256 (D.C. Cir. 1968).

79 Id. at 1262.

$80 \mathrm{Id}$.

81 United States v. Gilmore, 398 F.2d 679 (7th Cir. 1968); People v. Geralds, 29 App. Div. 2d 984, 290 N.Y.S.2d 10 (Sup. Ct. 1968) (dicta).

82407 F.2d 846 (4th Cir. 1969). 
ducted under laboratory conditions of an approved lineup." 83 In evaluating this attitude, it is important to recall that one of the primary reasons advanced by the police for avoiding holding lineups is that the procedure will unduly delay necessary identifications. However, prompt identification is defeated when the identification is postponed to the arraignment or the preliminary hearing and most certainly if the identification is postponed until the time of the trial itself. It may be argued that the premise of the "independent source" test which the Supreme Court put forward in the Wade opinion is that a victim or witness may give a reliable identification of an individual as late as the trial itself without the influence of a lineup. However, it appears that the definite suggestiveness of such an identification procedure carries the refutation of that premise, particularly since it is a suggestiveness that the presence of counsel cannot avert.

Finally, the costs to the legal system of the requirement of a mandatory lineup must be considered. They would undoubtedly be extensive, and because this is likely, it is worthwhile to consider alternative identification procedures, perhaps equally costly, but arguably more susceptible to legislative and judicial control than lineup identifications could ever become.

\section{Photographic Identifications}

One such alternative may lie in thoroughly controlled and reviewable photographic identification of criminal suspects. Such a procedure was suggested by Wigmore more than thirty years ago ${ }^{84}$ and was noted by the Court in Wade as one of the possible methods by which pretrial identification could be lifted from the "critical" category. ${ }^{85}$ Wigmore suggested that a file of at least 100 sound films would be prepared of various individuals. They would be photographed in certain movements and dress, and each would read aloud a stock statement. The suspect would be filmed in the same manner. Approximately twentyfive such films would be shown to the witnesses in a special projection room, where each identifier would press a button activating a board backstage which would indicate which person had been identified and by whom. Successive presses would indicate uncertainty of identification. ${ }^{86} \mathrm{~A}$ record could most certainly be kept which would indicate which films had been used in the identification procedure and

83 Id. at 847. Accord, Bowman v. State, 44 Ala. App. 331, 208 So. 2d 241 (Ct. App. 1968); Fogg v. Commonwealth, 208 Va. 541, 159 S.E.2d 616 (1968).

84 J. Wigmore, The Science of Judiclal. Proof 541 (3d ed. 1937).

85388 U.S. at 239 n.30.

$86 \mathrm{Id}$. 
which would indicate the results; the record would be available to defense counsel for use in trial preparation. A system designed on this type of model would solve the problems of suggestiveness and the problems of reconstruction of the identification process, at the same time eliminating an expensive utilization of counsel and eliminating the lineup identification which arguably can never be made sufficiently non-suggestive.

It is interesting to note that the photographic identification procedures which are now employed by the police have not been immune to challenge since the Wade-Gilbert decisions. The Supreme Court itself considered a due process challenge to a photographic identification in Simmons v. United States" and held that "convictions based on eyewitness identifications at trial following a pretrial identification by photograph will be set aside only if the photographic identification procedure was so impermissibly suggestive as to give rise to a very substantial likelihood of irreparable misidentification." 88 The test is very close to the one announced in Stovall for determining the due process validity of individual confrontations with the suspect. ${ }^{89}$ The petitioner in Simmons raised no claim of the right to counsel when the photographs were shown to the witnesses, ${ }^{90}$ and as far as can be determined from the opinion, the petitioner was not in police custody when the photographic showing was conducted. The Court noted that there were still dangers of misidentification, but that they could be limited by cross-examination at trial which exposed the possibilities of error. ${ }^{91}$ The Court also was aware of the widespread use of such photographic identification both in "apprehending offenders" and in "sparing innocent suspects the ignominy of arrest." 92

Further challenges have been made to photographic identification on due process grounds, ${ }^{93}$ and upon the grounds that there is a right to have counsel present when such photographic identifications are made. The reasoning behind the claim of a right to counsel at photographic identifications is essentially the same as that which prompted the Supreme Court to require counsel at lineups. The same possibilities for suggestiveness exist. For example, the police may show the

87390 U.S. 377 (1968).

$88 \mathrm{Id}$. at 384.

89388 U.S. at $301-2$.

90390 U.S. at 383.

91 Id. at 384.

$92 \mathrm{Id}$.

93 See, e.g., United States v. Trivette, 284 F. Supp. 720 (D.D.C. 1968); People v. Feggans, 67 Cal. 2d 444, 432 P.2d 21, 62 Cal. Rptr. 419 (1967); People v. Pedercine, 256 Cal. App. 2d 328, 63 Cal. Rptr. 873 (Ct. App. 1967). 
picture of the suspect whom they believe committed the crime several times during the display thus focusing attention on it.

Equally present is the difficulty of reconstructing the details of the photographic identification for purposes of cross-examination at trial, even though some courts feel such reconstruction is possible. ${ }^{94}$ Other courts have disagreed, and the District Court for the Eastern District of Pennsylvania noted that if the police were never able to produce the photos which were displayed to the witness, Wade might well have to be extended to this type of proceeding. ${ }^{95}$ In Simmons, the Supreme Court commented that it "would have been preferable for the Government to have labeled the pictures shown to each witness and kept them available for trial." 96 The difficulty of reconstructing the identification procedure may persist even when identification is made on the basis of a photographic display, and the danger is sufficient to warrant some further consideration of the issue by the courts and the police.

The problems of photographic identification cannot be readily solved by requiring the presence of counsel. Many photographic identifications are made before the suspect is taken into police custody, ${ }^{97}$ and counsel for any particular individual could not be required. Those courts which have considered the claim to the right to counsel at photographic identifications after a particular suspect is in custody have, with one exception, ${ }^{98}$ rejected the claim. ${ }^{99}$ The reason for the rejection is not totally clear. At least a part of it may be attributed to a desire not to push the sixth amendment beyond its present boundaries without guidance from the Supreme Court, ${ }^{100}$ but the other common denominator is found in the questionable assumption that there will be an opportunity to reconstruct the identification procedure at

94 United States v. Zeiler, 296 F. Supp. 224, 227 (W.D. Pa. 1969); United States v. Clark, 289 F. Supp. 610, 621 (E.D. Pa. 1968); People v. Padgitt, 264 Cal. App. 2d 443, 449 70 Cal. Rptr. 345, 349 (Ct. App. 1968).

95 United States v. Clark, 289 F. Supp. 610, 621 n.15 (E.D. Pa. 1968).

96 Simmons v. United States, 390 U.S. 377, 388 (1968) (footnotes omitted).

97 See, e.g., United States v. Robinson, 406 F.2d 64 (7th Cir. 1969); United States v. Trivette, 284 F. Supp. 720, 722 (D.D.C. 1968); State v. Carrothers, 79 N.M. 847, 443 P.2d 517 (Ct. App. 1968); People v. Jacobsen, 57 Misc. 2d 1046, 294 N.Y.S.2d 46 (Nassau Co. Ct. 1968); State v. Stamey, 3 N.C. App. 200, 164 S.E.2d 547 (Ct. App. 1968).

88 Thompson v. State, - Nev. -, 451 P.2d 704 (1969).

99 United States v. Bennett, 409 F.2d 888 (2d Cir. 1969): United States v. Marson, 408 F.2d 644 (4th Cir. 1968); United States v. Zeiler, 296 F. Supp. 224 (W.D. Pa. 1969); United States v. Clark, 289 F. Supp. 610 (E.D. Pa. 1968); People v. Padgitt, 264 Cal. App. 2d 443, 70 Cal. Rptr. 345 (Ct. App. 1968); Baldwin v. State, 5 Md. App. 22, 245 A.2d 98 (Ct. Spec. App. 1968); State v. Carrothers, 79 N.M. 347, 443 P.2d 517 (Ct. App. 1968). For criticism of United States v. Marson's refusal to extend Wade to photographic identifications see 43 N.Y.U.L. REv. 1019 (1968).

100 United States v. Bennett, 409 F.2d 888, 899 (2d Cir. 1969). 
trial.101 However, even if more courts ultimately do require counsel for photographic identifications conducted after the suspect is in custody, the value of the guarantee is speculative. The initial photographic identification which is conducted in the absence of counsel because the suspect is not in custody, even absent police manipulation, may well be sufficiently suggestive to destroy effectively the defendant's well-protected rights at later stages of identification. It is at the first stage, the initial photographic identification when the suspect is not in custody, that the protection must apply. In addition, the costs to the legal system of requiring counsel at photographic identifications when the suspect is in custody might again be prohibitive.

Stringent guidelines such as those described in the Wigmore model ${ }^{102}$ would assure that there was the opportunity to reconstruct the identification procedure at trial, and would be less costly than requiring counsel. Arguably the detailed procedure of the Wigmore model would not be possible if the suspect was not in custody, but there are other procedures which could be utilized in such a situation, still controlled by guidelines which would eliminate the possibility of suggestiveness. The more elaborate model should still be utilized after the suspect is in custody, particularly since the aim of the procedure is to eliminate the need to conduct the lineup at all.

Even if the guidelines imposed on the conduct of all photographic identifications do not have the effect of eliminating lineups, they still are necessary to protect the rights of the defendant. At present the physical identification confrontation is commonly preceded by a photographic identification. ${ }^{103}$ An unreviewable photographic identification could virtually destroy the suspect's rights at a lineup conducted in the most rigorous conformance with the Wade standards. ${ }^{104}$ This becomes even more apparent when the photographic identification is cited as part of the independent origin which makes a tainted lineup insufficient to bar the in-court identification of the witness, ${ }^{105}$ and when the photographic identification is the only out-of-court iden-

\footnotetext{
101 See text at notes 94-96 supra.

102 See text at notes 84-86 supra.

103 See, e.g., LeBlanc v. United States, 391 F.2d 916 (1st Cir. 1968); United States v. Hutto, 393 F.2d 783 (4th Cir. 1968); Cline v. United States, 395 F.2d 138 (8th Cir. 1968); Hanks v. United States, 388 F.2d 171 (10th Cir. 1968), cert. denied, 393 U.S. 863 (1969); United States v. Zeiler, 296 F. Supp. 224 (W.D. Pa. 1969); Bradley v. State, 206 So. 2d 657 (Fla. Ct. App. 1968); State v. Galloway, - Me. -, 247 A.2d 104 (1968); Tyler v. State, 5 Md. App. 265, 246 A.2d 634 (Ct. Spec. App. 1968).

104 United States v. Trivette, 284 F. Supp. 720, 723 (D.D.C. 1968).

105 See, e.g., LeBlanc v. United States, 391 F.2d 916, 917 (1st Cir. 1968); People r. Terczak, 96 Ill. App. 373, 379, 238 N.E.2d 626, 629 (Ct. App. 1968).
} 
tification arranged before the victim or witness testifies at trial..$^{108}$ Authoritative guidelines for the conduct of all photographic identification and the requirement of the production of the photographs displayed for the use of defense counsel would at least begin to solve the present problems. ${ }^{107}$

\section{CoNCLUSION}

At present, the protections of Wade and Gilbert are all too easily evaded by restrictive lower court interpretations of the scope of Wade, by expansive readings of the "independent source" test, and by the police avoiding the use of the lineup completely. The requirement of a mandatory lineup with counsel present and with guidelines promulgated for the conduct of the lineup must be combined with the guidelines for photographic identification, if the protections of the Wade and Gilbert decisions are to become a reality for the criminal defendant. Creative use of photographic identification under the control of enforceable guidelines could eliminate the problems of identification procedure in the future by substituting for the lineup a controlled, reviewable procedure where the risk of suggestiveness is eliminated and a record for the use of defense counsel is guaranteed.

\footnotetext{
106 See People v. Pettersen, 268 Cal. App. 2d -, 73 Cal. Rptr. 693 (Ct. App. 1968); State v. Hunsucker, 3 N.C. App. 281, 164 S.E.2d 507 (Ct. App. 1968). One state court had to deal with an ingenious variation of the photographic identification in Cox v. State, 219 So. 2d 762 (Fla. Ct. App. 1969). There the police had, without the suspect's knowledge, made a video tape of him as he was being booked, talking and walking. The video tape was later used for identification purposes. The court held that the defendant had a right to counsel at the time of this "secret confrontation between the victim and the defendant. What the police could not have done directly, they should not be allowed to do indirectly through the miracles of modern science." $I d$. at 765. The case amply illustrates the potential for abuse in the photographic identification.

107 The one court which has held that counsel is required when a suspect who is in police custody is identified from a group of pictures stated that it would not require counsel "if local law enforcement authorities would but preserve competently in the legal sense the photographs that are displayed to witnesses, provide guidelines for proper photographic identification procedures, and follow these guidelines." Thompson v. State, - Nev. -, 451 P.2d 704, 707 (1969).
} 